\title{
Effects of primary growth compared to regrowth grass silage on feed intake, growth performance and carcass traits of growing bulls
}

\author{
Arto Huuskonen ${ }^{1}$, Sari Rämö ${ }^{2}$ and Maiju Pesonen \\ ${ }^{1}$ Natural Resources Institute Finland (Luke), Production systems, Halolantie 31A, FI-71750 Maaninka, Finland \\ ${ }^{2}$ Natural Resources Institute Finland (Luke), Natural resources, Myllytie 1, FI-31600 Jokioinen, Finland \\ ${ }^{3}$ Natural Resources Institute Finland (Luke), Production systems, Survontie 9A, FI-40500 Jyväskylä, Finland \\ e-mail: arto.huuskonen@luke.fi
}

\begin{abstract}
The objective was to study the effects of primary growth vs. regrowth grass silage on intake, growth and carcass traits of growing bulls. In a feeding experiment, 30 bulls were offered a total mixed ration ad libitum. Two dietary treatments included either first or second cut grass silage (550 $\mathrm{g} \mathrm{kg}^{-1} \mathrm{dry}$ matter) supplemented with rolled barley (435 $\mathrm{g} \mathrm{kg}^{-1}$ dry matter) and a mineral-vitamin mixture ( $15 \mathrm{~g} \mathrm{~kg}^{-1} \mathrm{dry}$ matter). Feed and energy intake as well as the live weight gain of the bulls decreased when the second cut silage was used instead of the first cut silage. No differences in carcass conformation or carcass fat score between the treatments were observed. Analysed chemical, digestibility or fermentation parameters of the silage samples did not explain the differences in feed intake. However, some second cut silage samples were found to contain mycotoxins (zearalenone, roquefortine $\mathrm{C}$, mycophenolic acid and HT-2), but it is difficult to estimate whether this was the factor that affected feed intake in the present study.
\end{abstract}

Key words: beef production, bulls, feed intake, grass silage, mycotoxins

\section{Introduction}

Grass silage is the main forage offered to growing cattle in the Nordic countries. In Finland, two or three cuts are usually harvested from swards during the grass growing period and the digestibility is typically lower for regrowth grass compared with primary growth grass (Kuoppala 2010). The importance of grass silage digestibility for growing cattle is demonstrated in several studies (e.g. Steen 1988, Scollan et al. 2001, Keady et al. 2008, Manninen et al. 2011, Huuskonen et al. 2013a). Based on a meta-analysis, Huuskonen et al. (2013a) observed that a $1 \mathrm{~g} \mathrm{~kg}^{-1} \mathrm{dry}$ matter (DM) increase in digestible organic matter (DOM) in DM (D-value) increased grass silage DM intake (DMI) by $7.2 \mathrm{~g} \mathrm{~d}^{-1}$. Steen (1988) collated eight experiments in which grass silage was supplemented with concentrate feeds and reported that increasing grass silage digestibility increased live weight (LW) gain (LWG) and carcass gain by 37 and $28 \mathrm{~g}$, respectively, per $10 \mathrm{~g} \mathrm{~kg}^{-1}$ increase in DM digestibility.

In dairy cows, Kuoppala et al. (2008) observed a lower DMI of regrowth grass silage compared to late harvested primary growth silage, although most of the chemical and digestibility parameters were similar and the only marked difference was the higher neutral detergent fibre (NDF) concentration of primary growth silage. Nevertheless, the cows offered silage from primary growth consumed more silage and total DM and produced more milk compared to the cows offered silage from regrowth. Kuoppala et al. (2008) speculated that the microbiological quality of silage possibly contributed to the taste or palatability of regrowth silages, thus affecting silage DMI. Earlier, Peoples and Gordon (1989) and Heikkilä et al. (1998) also concluded that the lower milk production potential of autumn silages compared to spring silages was due to reduced silage DMI even though there were no differences between the digestibilities of the spring and autumn silages. In finishing Simmental bulls, Huuskonen and Pesonen (2017) observed that the intake and growth of bulls fed on second- and third-cut grass silages were lower than expected based on the feed analysis. One possible explanation for those unexpected intake and performance results might be mycotoxins in feeds since the presence of mycotoxins may decrease intake and affect performance (e.g. Yiannikouris and Jouany 2002). However, the knowledge of mycotoxin occurrence in animal feed was concentrated primarily on grains and cereals whereas silages, especially grass silages, have been studied less (Cheli et al. 2013). According to the literature, the most common mycotoxins in grass silage are zearalenone (ZON), mycophenolic acid (MPA), roquefortine C (ROC) and citrinin (CT) (Schneweis et al. 2000, Driehuis et al. 2008a, b). Occurrence of deoxynivalenol (DON) in grass silage is not as common as in maize silage (Cheli et al. 2013). 
The objective of the present experiment was to study the effects of primary growth compared to regrowth grass silage on feed intake, nutrient supply, growth performance and carcass traits of growing bulls. The experiment was designed to answer a question: Does the same digestibility in primary growth and in regrowth of grass silage affect the intake and growth performance of bulls in a similar way? Based on earlier studies, we hypothesised that the feed intake and growth of the regrowth silage fed bulls would be lower compared to primary growth fed bulls although there would not be major difference between the silage digestibilities. Because mycotoxin occurrence in grass silage is one possible explanation for lower intake, the most common mycotoxins in silages were analysed.

\section{Materials and methods}

\section{Animals and management}

A feeding experiment was carried out in the experimental cattle unit of Natural Resources Institute Finland (Luke) in Siikajoki, Finland starting in February 2016 and ending in August 2016. The animals were managed according to Finnish legislation regarding the use of animals in scientific experimentation. The experiment comprised 30 purebred Hereford (HF) bulls which were purchased from three commercial herds and were from six different sires. The bulls were born in spring 2015 and spent their first summer at pasture with their dams. In November 2015, the bulls were weaned and transferred to the experimental barn of Luke. During the pre-experimental period of three months (from November to February), all the bulls were housed in an uninsulated barn in group pens and offered similar feeds (grass silage, rolled barley, mineral mixture and vitamin mixture). At the start of the feeding experiment, the bulls weighed $369( \pm 47.5) \mathrm{kg}$ and were $304( \pm 29.5)$ days old, on average.

During the feeding experiment, the bulls were housed in an uninsulated barn in pens $(10.0 \times 5.0 \mathrm{~m} ; 5$ bulls in each pen), providing $10.0 \mathrm{~m}^{2}$ of space per bull. The rear half of the pen area was a straw-bedded lying area and the fore half was a feeding area with a solid concrete floor. A GrowSafe feed intake system (model 4000E; GrowSafe Systems Ltd., Airdrie, AB, Canada) was used to record individual daily feed intakes so that each pen contained two GrowSafe feeder nodes. The bulls had free access to water from a water bowl (one bowl/pen) during the experiment.

\section{Feeding and experimental design}

Grass silages were produced at the experimental farm of Luke in Siikajoki $\left(64^{\circ} 44^{\prime} \mathrm{N}, 25^{\circ} 15^{\prime} \mathrm{E}\right)$ and harvested from the first-year timothy (Phleum pratense cv. Tuure) stands on 25 June and 11 August 2015; first and second cut, respectively. The aim was to have both timothy silages with D-value of $690 \mathrm{~g} \mathrm{~kg}^{-1} \mathrm{DM}$, and to determine the optimal harvesting time, herbage samples were taken every second day and D-value was analysed by near-infrared spectroscopy as described by Nousiainen et al. (2004). The stands were cut by a mower conditioner (Elho $280 \mathrm{Hy}$ dro Balance; Oy Elho Production Ab, Pännäinen, Finland) and harvested with an integrated round baler wrapper (McHale Fusion 3; McHale, Ballinrobe, Co. Mayo, Ireland) 24 hours after cutting. Six layers of plastic were applied and the bales were stored in the field. Both silages were treated with a formic acid-based additive (AIV ÄSSÄ; Eastman Chemical Company, Oulu, Finland; $589 \mathrm{~g}$ formic acid kg-1 $199 \mathrm{~g}$ propionic acid $\mathrm{kg}^{-1}, 43 \mathrm{~g}$ ammonium formate $\mathrm{kg}^{-1}$ and $25 \mathrm{~g}$ potassium sorbate $\mathrm{kg}^{-1}$ ) applied at a rate of $5.8 \mathrm{~kg} \mathrm{t}^{-1}$ of fresh forage.

At the beginning of the feeding experiment, the bulls were randomly allotted to pens which were then randomly allotted to one of the two feeding treatments (six pens in total, three pens per treatment and five animals per pen). The first treatment (GS1) included first cut grass silage (550 $\left.\mathrm{g} \mathrm{kg}^{-1} \mathrm{DM}\right)$, rolled barley (435 $\left.\mathrm{g} \mathrm{kg}^{-1} \mathrm{DM}\right)$ and mineral-vitamin mixture (15 $\left.\mathrm{g} \mathrm{kg}^{-1} \mathrm{DM}\right)$ while the second treatment (GS2) included second cut grass silage (550 $\left.\mathrm{g} \mathrm{kg}^{-1} \mathrm{DM}\right)$, rolled barley (435 $\left.\mathrm{g} \mathrm{kg}^{-1} \mathrm{DM}\right)$ and a mineral-vitamin mixture (15 $\left.\mathrm{g} \mathrm{kg}^{-1} \mathrm{DM}\right)$. The composition of the mineral-vitamin mixture (Kasvuape E-Hiven; A-Rehu Ltd., Seinäjoki, Finland) is fully described by Huuskonen et al. (2017). The bulls were offered a total mixed ration ad libitum (proportionate refusals of 5\%). Total mixed rations were carried out by a mixer wagon (Trioliet; BW Oldenzaal, the Netherlands) once a day.

\section{Feed sampling and analysis}

During the feeding experiment, silage subsamples were taken twice a week while total mixed rations were carried out, pooled over periods of four weeks and stored at $-20^{\circ} \mathrm{C}$ prior to analysis. There were no visible moulds on the silages. Thawed samples were analysed for DM, ash, crude protein (CP), NDF exclusive of residual ash, crude fat (analysed as ether extracts), silage fermentation quality ( $\mathrm{pH}$, water-soluble carbohydrates [WSC], lactic and formic acids, volatile fatty acids [VFA], soluble and ammonia N content of total N), D-value and mycotoxins. Barley subsamples were collected weekly, pooled over periods of eight weeks and analysed for DM, ash, CP, NDF and crude fat. 
Thawed silage samples were analysed for fermentation quality by electrometric titration as described by Moisio and Heikonen (1989). The DM concentration was determined by drying at $105^{\circ} \mathrm{C}$ for $20 \mathrm{~h}$. Samples for chemical analysis were dried at $60^{\circ} \mathrm{C}$ for $16 \mathrm{~h}$ and milled using a sample mill (Sakomylly KT-120; Koneteollisuus Ltd., Helsin$\mathrm{ki}$, Finland) using a $1 \mathrm{~mm}$ sieve. Oven DM concentration of silages was corrected for the loss of volatiles according to Huida et al. (1986). The ash, CP, NDF and crude fat concentrations as well as D-value were determined as reported by Huuskonen and Pesonen (2018). The metabolisable energy (ME) concentration of the silages was calculated as $0.016 \times$ D-value (MAFF 1984). The ME concentration of barley grain was calculated based on concentrations of digestible crude fibre, CP, crude fat and nitrogen-free extract as described by Luke (2018). Crude fibre concentrations and digestibility coefficients were taken from the Finnish Feed Tables (Luke 2018). The values of metabolisable protein (MP) and the protein balance in the rumen (PBV) were calculated according to the Finnish feed protein evaluation system (Luke 2018) in which MP describes the amount of amino acids absorbed from the small intestine and PBV describes the balance between the dietary supply of rumen-degradable protein (RDP) and the microbial requirements for RDP. The relative intake potential of silage DM (SDMI index) was calculated as described by Huhtanen et al. (2007).

The silage samples were analysed for mycotoxins at the lab of Luke in Jokioinen, Finland. Mycotoxin standards were purchased either Sigma-Aldrich (St. Louis, Missouri, USA) or Romer Labs Diagnostics Gmbh (Tulln, Austria). The determined trichothecenes were DON, diacetoxyscirpenol (DAS), 3-and 15-acetyldeoxynivalenols (3-AcDON and 15-AcDON), nivalenol (NIV), fusarenon-X (F-X), T-2 and HT-2 toxins (T-2 and HT-2). Other determined mycotoxins were ZON, ROC, MPA, CT, fumonisins B1, B2 and B3, aflatoxins B1, B2, G1 and G2, sterigmatocystin, ochratoxin A, cyclopiazonic acid, alternariol, patulin, ergocornine, tenuatzonic acid, moniliformin and beauvericin. Penicillic acid and gliotoxin were not analysed, because the commercial standards were not available.

Trichothecenes were quantified by GC-MS -method: extracted with acetonitrile:water (84:16), cleaned up with MycoSep \#227 column (RomerLabs Diagnostics Gmbh, Tulln, Austria), and identified as their trimethylsilyl imidazole (TMSI; Thermo Fisher Scientific,Waltham, MA, USA) derivatives with GC-MS (Agilent 6890 N-5973; Agilent Technologies, Santa Clara, CA, USA) (Hietaniemi et. al. 2004). 19-nortestosterone (250 $\mu \mathrm{l}, 1000 \mathrm{ng} \mathrm{ml}^{-1}$; Fluka/ Riedel-de Haën, Buchs, Switzerland) was used as the internal standard in the selective ion monitoring method (SIM) (Table 1). The results were confirmed with recovery tests in samples with three different concentrations.

\begin{tabular}{|c|c|c|c|c|c|}
\hline $\begin{array}{l}\text { Trichothecene } \\
\text { (TMSI derivative) }\end{array}$ & Retention time, min & Target ion & Q1 & Q2 & Q3 \\
\hline deoxynivalenol & 12.39 & 235 & 422 & 512 & \\
\hline diacetoxyscirpenol & 13.89 & 378 & 350 & 290 & \\
\hline 3-acetyldeoxynivalenol & 14.08 & 392 & 467 & 377 & \\
\hline 15-acetyldeoxynivalenol & 14.48 & 392 & 467 & 350 & 407 \\
\hline fusarenon-X & 14.53 & 251 & 480 & 450 & \\
\hline nivalenol & 15.66 & 289 & 482 & 349 & 379 \\
\hline T-2 & 22.66 & 350 & 436 & 290 & \\
\hline HT-2 & 23.05 & 347 & 466 & 275 & 377 \\
\hline ISTD 19-nortestosterone & 18.31 & 346 & 256 & 331 & 215 \\
\hline
\end{tabular}

Other mycotoxins (Table 2) were extracted according Bourdra et al. (2015) with some modifications: One gram of freeze dried grass silage sample (fresh weight $5.8 \mathrm{~g} \pm 0.1 \mathrm{~g}$ ) was weighted in a $50 \mathrm{ml}$ roQQuEChERS extraction tube (KS0-8909, Phenomenex, Torrance, CA, USA) containing trisodium citrate dihydrate $(1 \mathrm{~g})$, disodium hydrogencitrate sesquihydrate $(0.5 \mathrm{~g}), \mathrm{NaCl}(1 \mathrm{~g})$ and $\mathrm{MgSO}_{4}(4 \mathrm{~g})$. 19-nortestosterone (250 ul, $1000 \mathrm{ng} \mathrm{ml}^{-1}$ ) was added as internal standard in sample. In case of a matrix matched calibration sample and recovery sample, known volumes of known standard mix solutions were added to the tube. Two different extraction procedures were done: either a) $10 \mathrm{ml}$ of distilled water or b) $10 \mathrm{ml}$ of distilled water containing $1 \%$ of acetic acid were added. The tubes were mixed using a Vortex blender. After complete absorption of the water solution, either a) $10 \mathrm{ml}$ of acetonitrile or b) $10 \mathrm{ml}$ of $1 \%$ of acetic acid in acetonitrile were added. 
Table 2. Retention times, ionisation modes, molecular weights (Mw), multiple reaction monitoring settings (MRM), cone voltages (Cone) and collision energies (Coll.) for mycotoxins determined with UPLC-MS/MS. Bold MRMs were used for identification, other as qualifiers.

\begin{tabular}{|c|c|c|c|c|c|c|}
\hline Mycotoxin & $\begin{array}{l}\text { Retention time } \\
\text { (min) }\end{array}$ & lonisation mode & $\mathrm{Mw}$ & MRM & $\begin{array}{l}\text { Cone } \\
\text { (V) }\end{array}$ & $\begin{array}{l}\text { Coll. } \\
(\mathrm{eV})\end{array}$ \\
\hline Moniliformin & 0.77 & ESI - & 98 & $96.9->40.9$ & 27 & 10 \\
\hline \multirow[t]{3}{*}{ Patulin } & 3.37 & $\mathrm{ESI}+$ & 154 & $155->52.9$ & 15 & 20 \\
\hline & & & & $155->70.9$ & 15 & 20 \\
\hline & & & & $155->80.9$ & 15 & 20 \\
\hline \multirow[t]{2}{*}{ Aflatoxin G2 } & 5.74 & $\mathrm{ESI}+$ & 330 & $331.2->189.1$ & 32 & 42 \\
\hline & & & & $331.2->245.2$ & 32 & 30 \\
\hline \multirow[t]{2}{*}{ Aflatoxin G1 } & 5.96 & $\mathrm{ESI}+$ & 328 & $329.2->243.1$ & 20 & 26 \\
\hline & & & & $329.2->199.8$ & 22 & 44 \\
\hline \multirow[t]{2}{*}{ Aflatoxin B2 } & 5.97 & $\mathrm{ESI}+$ & 314 & $315.2->287.2$ & 20 & 26 \\
\hline & & & & 315.2 -> 259.1 & 20 & 32 \\
\hline \multirow[t]{3}{*}{ Ergocornine } & $5.99-6.2$ & $\mathrm{ESI}+$ & 562 & $563->277$ & 35 & 30 \\
\hline & & & & $563->305$ & 35 & 30 \\
\hline & & & & $563->348$ & 35 & 30 \\
\hline \multirow[t]{2}{*}{ Tenuazonic acid } & 6.13 & ESI - & 197 & $196.1->139.0$ & 50 & 20 \\
\hline & & & & $196.1->112.0$ & 50 & 24 \\
\hline \multirow[t]{2}{*}{ Fumonisin B1 } & 6.17 & $\mathrm{ESI}+$ & 721 & 722.1 -> 334.3 & 50 & 40 \\
\hline & & & & 722.1 -> 352.3 & 50 & 40 \\
\hline \multirow[t]{2}{*}{ Aflatoxin B1 } & 6.22 & $\mathrm{ESI}+$ & 312 & $313.2->241.2$ & 20 & 40 \\
\hline & & & & 313.2 -> 285 & 20 & 24 \\
\hline \multirow[t]{2}{*}{ Roquefortine C } & 6.41 & $\mathrm{ESI}+$ & 389 & $390.2->322.2$ & 27 & 19 \\
\hline & & & & 390.2 -> 193 & 27 & 28 \\
\hline \multirow[t]{2}{*}{ Alternariol } & 6.42 & ESI - & 258 & 257.1 -> 215.0 & 22 & 32 \\
\hline & & & & $257.1->147.0$ & 22 & 32 \\
\hline \multirow[t]{2}{*}{ Fumonisin B3 } & 6.63 & $\mathrm{ESI}+$ & 705 & $706.3->336.3$ & 50 & 40 \\
\hline & & & & 706.3 -> 318.3 & 50 & 40 \\
\hline \multirow[t]{3}{*}{ Citrinin } & 6.94 & $\mathrm{ESI}+$ & 250 & 251.2 -> 191 & 14 & 26 \\
\hline & & & & $251.2->205.1$ & 14 & 24 \\
\hline & & & & 251.2 -> 91.0 & 14 & 40 \\
\hline \multirow[t]{2}{*}{ Fumonisin B2 } & 6.9 & $\mathrm{ESI}+$ & 705 & $706.3->336.3$ & 50 & 40 \\
\hline & & & & 706.3 -> 318.3 & 50 & 40 \\
\hline \multirow[t]{2}{*}{ Mycophenolic acid } & 7.08 & $\mathrm{ESI}+$ & 320 & $321.2->207.1$ & 14 & 22 \\
\hline & & & & $321.2->159.0$ & 14 & 36 \\
\hline \multirow[t]{2}{*}{ Zearalenone } & 7.87 & ESI - & 318 & $317.2->175.0$ & 42 & 26 \\
\hline & & & & $317.2->131.0$ & 42 & 30 \\
\hline \multirow[t]{2}{*}{ Ochratoxin A } & 7.89 & $\mathrm{ESI}+$ & 403 & $404.2->239.1$ & 25 & 32 \\
\hline & & & & $404.2->358.2$ & 25 & 20 \\
\hline \multirow[t]{4}{*}{ Sterigmatocystin } & 8.1 & $\mathrm{ESI}+$ & 324 & $325.2->310.1$ & 8 & 20 \\
\hline & & & & $325.2->115.1$ & 8 & 60 \\
\hline & & & & $325.2->253.2$ & 8 & 46 \\
\hline & & & & $325.2->141.1$ & 8 & 54 \\
\hline \multirow[t]{2}{*}{ Cyclopiazonic acid } & 8.57 & $\mathrm{ESI}+$ & 336 & 337.1 -> 196 & 22 & 26 \\
\hline & & & & 337.1 -> 182 & 22 & 20 \\
\hline \multirow[t]{4}{*}{ Beauvericin } & 11.0 & $\mathrm{ESI}+$ & 783 & 784.6 -> 262.2 & 34 & 28 \\
\hline & & & & $784.6->244.2$ & 34 & 28 \\
\hline & & & & $784.6->134.1$ & 34 & 66 \\
\hline & & & & 784.6 -> 234.2 & 34 & 38 \\
\hline
\end{tabular}


First, tubes were shaken vigorously until the pressure dissipated, then they were mixed with a Vortex blender for two minutes and finally centrifuged (2000 rpm, $5 \mathrm{~min}$ ). One $\mathrm{ml}$ of extracts were filtered through a $0.2 \mu \mathrm{m}$ GHP Acrodisc 13 (Pall Corporation, New York, NY, USA) in vials for the UPLC-MS/MS run (Waters Acquity Xevo TQ MS; Waters, Milford, MA, USA) according Stead et al. (2014) with some modifications: Mycotoxins were separated with BEH C18 column $1.7 \mu \mathrm{m}$ (Guard column $2.1 \times 5$ mm, Analytical column $2.1 \times 100 \mathrm{~mm}$; Waters, Milford, MA, USA), using a gradient solvent system (solvent $A=0.1 \%$ formic acid in water and solvent $B=0.1 \%$ formic acid in acetonitrile). The gradient conditions were as follows: the initial percentage of solvent $B$ was $0 \%$, because to get retention also for moniliformin, it was held at $0 \%$ for $1.5 \mathrm{~min}$, then increased to $100 \%$ to $12 \mathrm{~min}$ and maintained for $1 \mathrm{~min}$. It was then lowered to the initial $0 \%$ in $0.1 \mathrm{~min}$, and maintained for $1.9 \mathrm{~min}$ to re-equilibrate the column prior to the next injection. MS capillary voltage was set at $3.5 \mathrm{kV}$, source temperature at $150{ }^{\circ} \mathrm{C}$, and desolvation temperature at $500{ }^{\circ} \mathrm{C}$. The cone and desolvation gas flows (both nitrogen) were set at 30 and $1000 \mathrm{I} \mathrm{h}$, respectively. Data was acquired using the multiple reaction monitoring (MRM) scanning mode. The calibration samples were first run during December 2017 and again during February 2018. The samples (also recovery samples) were extracted and run during February 2018. Finally, an external standard method was used for quantification. It was found that citrinin is not stable in extract and that moniliformin and patulin could not be quantified due to matrix interferences. Any clear differences between responses of mycotoxins were not found between the two different extractions.

Matrix-matched calibration samples were cleaned up according to Bourdra et al. (2015) with some modifications: Two different clean-up procedures were done for both extractions: a) One $\mathrm{ml}$ of acetonitrile phase was transferred to a $2 \mathrm{ml}$ roQ QuEChERS dSPE tube (KS0-8916; Phenomenex, Torrance, CA, USA), containing $0.15 \mathrm{~g} \mathrm{MgSO}_{4}$ and $0.025 \mathrm{~g}$ PSA (primary secondary amine), b) About $7.5 \mathrm{mg}$ of graphitised carbon black (Sepra GCB, 04D-4615; Phenomenex, Torrance, CA, USA) was added before the extract into a $2 \mathrm{ml}$ tube in order to remove pigments such as carotenoids and chlorophyll from the sample. First, tubes were shaken vigorously until the pressure dissipated, then they were mixed with a Vortex blender for two minutes and finally centrifuged ( $2000 \mathrm{rpm}, 5 \mathrm{~min}$ ). One $\mathrm{ml}$ of extracts were filtered through a $0.2 \mu \mathrm{m}$ GHP Acrodisc 13 (Pall Corporation, New York, NY, USA) into vials. The responses of most mycotoxins were lower in all four cleaned-up calibrants than the calibrants that had not been cleaned up in UPLC-MS/MS runs, and so silage samples were quantified without cleaning up the extracts. Concentrating of extracts to dryness and resolving to UPLC gradient ( $0.1 \%$ water: acetonitrile $1: 1)$ would possibly help to quantify moniliformin and patulin.

\section{Carcass traits and ultrasound measurements}

The bulls were weighed on two consecutive days at the beginning of the experiment and thereafter single weighings were done approximately every 28 days. Before slaughter, the bulls were weighed on two consecutive days. The bulls were weighed always at the same time in the morning before feeding. The target for the average carcass weight was $350 \mathrm{~kg}$, which is near the average carcass weight for slaughtered Hereford bulls in Finland (Pesonen and Huuskonen 2015). The LWG was calculated as the difference between the means of the initial and final LW divided by the number of growing days. The estimated rate of carcass gain was calculated as the difference between the final carcass weight and the carcass weight at the beginning of the experiment divided by the number of growing days. The carcass weight at the start of the experiment was assumed to be $0.52 \times$ initial LW based on earlier studies (unpublished data).

Ultrasound measurements were made one day before slaughter. Ultrasound subcutaneous fat $(\mathrm{mm})$ at the $1^{\text {st }}$ lumbar vertebra, ultrasound depth $(\mathrm{cm})$ of longissimus dorsi muscle at the $1^{\text {st }}$ lumbar vertebrae and ultrasound intramuscular fat (IMF) (\%) were performed as described by Huuskonen and Pesonen (2017) with a Pie 200 SLC scanner (FPS 8; DFR 2-4 inches; Esaote, Genoa, Italy) equipped with the QUIP (Quality Ultrasound Indexing Program) software (Version 2.6) and a ASP-18 transducer (3.5 MHz) without a stand-off pad.

The bulls were selected for slaughter based on LW, and slaughtered in the commercial slaughterhouse of Atria Ltd. in Kauhajoki, Finland in three batches. Both feeding treatments were represented in all batches. The transport to the slaughterhouse lasted five hours. The bulls from different pens were not mixed during the transportation. After slaughter, the carcasses were weighed hot. The cold carcass weight was estimated as 0.98 of the hot carcass weight. Dressing proportions were calculated from the ratio of cold carcass weight to final LW. The carcasses were visually classified for conformation and fatness using the EUROP quality classification (EC 2006). 


\section{Statistical methods}

The results are shown as least squares means. The data were subjected to analysis of variance using the SAS GLM procedure (version 9.4, SAS Institute Inc., Cary, NC, USA). The statistical model used was

$$
y_{i j k l}=\mu+\delta_{j}+\alpha_{i}+\theta_{i j l}+\beta x_{i j k}+e_{i j k l}
$$

where $\mu$ is the intercept and $e_{i j k l}$ is the residual error term associated with $k^{\text {th }}$ animal. $\alpha_{i}$, is the effect of $i^{\text {th }}$ diet (GS1, GS2), while $\delta_{j}$ is the effect of the slaughtering batch $(j=1,2,3)$ and $\theta_{i j l}$ is the effect of the pen. The effect of the pen was used as an error term when differences between treatments were compared because treatments were allocated to animals penned together. Initial LW was used as a covariate $\left(\beta \mathrm{x}_{\mathrm{ijk}}\right)$ in the model for intake, gain, feed conversion, final LW, carcass characteristics and ultrasound measurements.

\section{Results}

Chemical composition and feeding values of the feeds and total mixed rations are presented in Table 3. The D values of the silages were 697 and $683 \mathrm{~g} \mathrm{~kg}^{-1} \mathrm{DM}$ for the first and second cut, respectively, and very close to the preplanned D value ( $\left.690 \mathrm{~g} \mathrm{~kg}^{-1} \mathrm{DM}\right)$. The two silages had similar concentrations of ME, CP, AAT and PBV. However, the first cut silage had a $31 \%$ lower DM and $12 \%$ higher NDF concentration compared to the second cut silage. The second cut silage had a 7\% higher SDMI index compared to the first cut silage. The fermentation characteristics of both silages were good as indicated by the low $\mathrm{pH}$ value and the low concentrations of ammonia $\mathrm{N}$ in total $\mathrm{N}$ and total fermentation acids (Table 3). Both silages were restrictively fermented with a high residual WSC concentration and a relatively low lactic acid concentration. However, the WSC concentration of the first cut silage was clearly lower compared to the second cut silage.

Table 3. Chemical composition and feeding values (mean \pm standard deviation) of the ingredients and total mixed rations (calculated) used in the feeding experiment.

\begin{tabular}{|c|c|c|c|c|c|}
\hline & \multicolumn{3}{|c|}{ Feeds } & \multicolumn{2}{|c|}{ Total mixed rations } \\
\hline & $\begin{array}{l}\text { Grass silage } \\
\text { first cut }\end{array}$ & $\begin{array}{l}\text { Grass silage } \\
\text { second cut }\end{array}$ & Barley & $\mathrm{GS}^{1}$ & $\mathrm{GS}^{2}$ \\
\hline Number of feed samples & 6 & 6 & 3 & & \\
\hline Dry matter (DM), $\mathrm{g} \mathrm{kg}^{-1}$ & $229 \pm 28.3$ & $331 \pm 20.8$ & $872 \pm 6.4$ & 343 & 459 \\
\hline Organic matter (OM), $\mathrm{g} \mathrm{kg}^{-1} \mathrm{DM}$ & $944 \pm 4.8$ & $933 \pm 4.0$ & $971 \pm 0.9$ & 956 & 950 \\
\hline Crude protein, $\mathrm{g} \mathrm{kg}^{-1} \mathrm{DM}$ & $149 \pm 17.3$ & $151 \pm 16.2$ & $115 \pm 11.7$ & 133 & 135 \\
\hline Neutral detergent fibre, $\mathrm{g} \mathrm{kg}^{-1} \mathrm{DM}$ & $595 \pm 24.4$ & $532 \pm 8.2$ & $211 \pm 10.4$ & 422 & 387 \\
\hline Crude fat, $\mathrm{g} \mathrm{kg}^{-1} \mathrm{DM}$ & $34 \pm 0.8$ & $35 \pm 1.0$ & $22 \pm 0.9$ & 29 & 29 \\
\hline Metabolisable energy, $\mathrm{MJ} \mathrm{kg}^{-1} \mathrm{DM}$ & $11.1 \pm 0.41$ & $10.9 \pm 0.17$ & $12.9 \pm 0.04$ & 11.9 & 11.8 \\
\hline Metabolisable protein, $\mathrm{g} \mathrm{kg}^{-1} \mathrm{DM}$ & $84 \pm 4.5$ & $83 \pm 2.2$ & $95 \pm 1.5$ & 89 & 88 \\
\hline Protein balance in the rumen, $\mathrm{g} \mathrm{kg}^{-1} \mathrm{DM}$ & $24 \pm 9.6$ & $27 \pm 9.3$ & $-27 \pm 8.6$ & 1 & 3 \\
\hline Digestible OM in DM, $\mathrm{g} \mathrm{kg}^{-1} \mathrm{DM}$ & $697 \pm 13.4$ & $683 \pm 10.4$ & $821 \pm 3.3$ & 753 & 745 \\
\hline Silage DM intake index & $99 \pm 2.7$ & $106 \pm 2.8$ & & & \\
\hline \multicolumn{6}{|l|}{ Fermentation quality of silages } \\
\hline $\mathrm{pH}$ & $3.90 \pm 0.148$ & $4.27 \pm 0.120$ & & & \\
\hline Volatile fatty acids, $\mathrm{g} \mathrm{kg}^{-1} \mathrm{DM}$ & $15 \pm 1.6$ & $7 \pm 1.2$ & & & \\
\hline Lactic + formic acid, $\mathrm{g} \mathrm{kg}^{-1} \mathrm{DM}$ & $49 \pm 3.5$ & $35 \pm 5.7$ & & & \\
\hline $\begin{array}{l}\text { Water soluble carbohydrates, } \\
\mathrm{g} \mathrm{kg}^{-1} \mathrm{DM}\end{array}$ & $56 \pm 15.8$ & $118 \pm 10.9$ & & & \\
\hline \multicolumn{6}{|l|}{ In total $\mathrm{N}, \mathrm{g} \mathrm{kg}^{-1}$} \\
\hline $\mathrm{NH}_{4} \mathrm{~N}$ & $66 \pm 3.6$ & $55 \pm 3.3$ & & & \\
\hline Soluble N & $555 \pm 36.4$ & $478 \pm 30.1$ & & & \\
\hline
\end{tabular}


Barley grain used in the present experiment had typical chemical composition and feed values, corresponding to the average values in the Finnish Feed Tables. Due to differences in the composition of the experimental silages, the GS1 ration contained slightly more NDF compared to the GS2 ration (Table 3). In both rations the PBV value fulfilled the Finnish recommendation for growing cattle (PBV of the diet above $-10 \mathrm{~g} / \mathrm{kg}$ DM for animals above $200 \mathrm{~kg} L W$ ).

None of the first cut grass silage samples was found to contain any analysed mycotoxins. Instead, four out of six second cut silage samples were found to contain ZON and two of the six samples were found to contain ROC and MPA. All the above observations were $<50 \mu \mathrm{g} \mathrm{kg}^{-1}$. Mycotoxin HT-2 was detected in one second cut silage sample at a concentration lower than $110 \mu \mathrm{g} \mathrm{kg}^{-1}$, which was the lowest concentration of quantification (LOQ) for trichothecenes in silage. Other analysed toxins were not observed.

The average duration of the feeding experiment was 167 and 180 days for the GS1 and GS2 treatments, respectively (Table 4). The use of first cut silage increased DM ( $p<0.01), \operatorname{ME}(p<0.001), \operatorname{CP}(p<0.01), \operatorname{MP}(p<0.001)$ and NDF $(p<0.001)$ intakes compared to second cut silage. The average LWG of the GS1 bulls was $11 \%$ higher $(p<0.01)$ and daily carcass gain tended to be $7 \%$ higher $(p<0.10)$ compared to the GS2 bulls. Dietary treatments had no effects on DM, energy or protein conversion rates (Table 4).

\begin{tabular}{|c|c|c|c|c|}
\hline & \multicolumn{2}{|c|}{ Feedings } & \multirow[b]{2}{*}{$\mathrm{SEM}^{3}$} & \multirow[b]{2}{*}{$p$-value } \\
\hline & $\mathrm{GS}^{1}$ & $\mathrm{GS}^{2}$ & & \\
\hline Duration of the experiment, $d$ & 167 & 180 & 3.9 & 0.033 \\
\hline Final live weight (LW), $\mathrm{kg}$ & 654 & 649 & 8.0 & 0.752 \\
\hline Slaughter age, $d$ & 467 & 488 & 7.5 & 0.058 \\
\hline \multicolumn{5}{|l|}{ Intake } \\
\hline Total, kg dry matter (DM) $d^{-1}$ & 9.93 & 9.17 & 0.161 & 0.002 \\
\hline DM intake, $\mathrm{g} \mathrm{kg}^{-1}$ metabolic $\mathrm{LW}^{4}$ & 92.6 & 85.3 & 1.33 & $<0.001$ \\
\hline Metabolisable energy (ME), $\mathrm{MJ} \mathrm{d}^{-1}$ & 119 & 108 & 1.9 & $<0.001$ \\
\hline Metabolisable protein, $\mathrm{g} \mathrm{d}^{-1}$ & 879 & 806 & 14.2 & $<0.001$ \\
\hline Crude protein, $\mathrm{g} \mathrm{d}^{-1}$ & 1309 & 1220 & 22.1 & 0.005 \\
\hline Neutral detergent fibre, $\mathrm{g} \mathrm{d}^{-1}$ & 4156 & 3522 & 66.3 & $<0.001$ \\
\hline Live weight gain (LWG), $\mathrm{g} \mathrm{d}^{-1}$ & 1717 & 1543 & 39.4 & 0.005 \\
\hline Carcass gain, $\mathrm{g} \mathrm{d}^{-1}$ & 923 & 862 & 23.8 & 0.098 \\
\hline \multicolumn{5}{|l|}{ Feed conversion } \\
\hline $\mathrm{kg} \mathrm{DM} \mathrm{kg}^{-1} \mathrm{LWG}$ & 5.78 & 5.94 & 0.137 & 0.611 \\
\hline $\mathrm{kg} \mathrm{DM} \mathrm{kg}^{-1}$ carcass gain & 10.76 & 10.64 & 0.261 & 0.704 \\
\hline MJ ME kg-1 LWG & 69.3 & 70.0 & 1.61 & 0.806 \\
\hline MJ ME kg-1 carcass gain & 128.9 & 125.3 & 3.07 & 0.522 \\
\hline $\mathrm{g}$ crude protein $\mathrm{kg}^{-1} \mathrm{LWG}$ & 762 & 791 & 17.6 & 0.383 \\
\hline $\mathrm{g}$ crude protein $\mathrm{kg}^{-1}$ carcass gain & 1418 & 1415 & 32.9 & 0.955 \\
\hline \multicolumn{5}{|l|}{ Carcass characteristics } \\
\hline Carcass weight, kg & 345 & 348 & 5.0 & 0.528 \\
\hline Dressing proportion, $\mathrm{g} \mathrm{kg}^{-1}$ & 527 & 537 & 3.7 & 0.070 \\
\hline Conformation, EUROP & 8.1 & 8.1 & 0.22 & 0.957 \\
\hline Fat score, EUROP & 2.9 & 3.2 & 0.15 & 0.213 \\
\hline \multicolumn{5}{|l|}{ Ultrasound measurements } \\
\hline Subcutaneous rump fat, $\mathrm{mm}$ & 6.4 & 6.6 & 0.26 & 0.584 \\
\hline Intramuscular fat, \% & 3.5 & 3.5 & 0.11 & 0.575 \\
\hline Depth of longissimus dorsi muscle, $\mathrm{cm}$ & 7.0 & 7.0 & 0.16 & 0.951 \\
\hline
\end{tabular}


The mean carcass weight of the bulls was $347 \mathrm{~kg}$ and very close to the pre-planned weight. There was no difference in carcass weight, carcass conformation, carcass fat score or ultrasound measurements between the feeding treatments (Table 4). However, the dressing proportion of the GS2 bulls tended to be $2 \%$ higher $(p<0.10)$ compared to the GS1 bulls.

\section{Discussion}

The DM concentration of the first cut silage was 31\% lower compared to the second cut silage, which was due to rainy conditions during the first cut. Because the aim was to have both silages with a D-value of $690 \mathrm{~g} \mathrm{~kg}^{-1} \mathrm{DM}$, it was not possible to wait for better weather conditions for the first cut. The second cut silage had a higher SDMI index compared to the first cut silage. The difference in the DM content affected the SDMI index, as a meta-analysis by Huhtanen et al. (2007) implied that SDMI is independently affected by silage DM concentration. Huhtanen et al. (2007) observed that silage DMI of dairy cows increased quadratically with increasing silage DM concentration. Also, many earlier data evaluations have reported a positive association between forage DM concentration and DMI in both dairy cows and growing cattle (e.g. Offer et al. 1998, Steen et al. 1998, Wright et al. 2000). Steen et al. (1998) observed that the maximum forage intake was achieved at a DM concentration of $320 \mathrm{~g} \mathrm{~kg}^{-1} \mathrm{while}^{-}$ Huhtanen et al. (2007) reported that the maximum intake was predicted at a DM concentration of $419 \mathrm{~g} \mathrm{~kg}^{-1}$.

Based on SDMI index, the intake response of the second cut silage should have been higher compared to the first cut silage. Nevertheless, daily DMI was higher when the GS1 ration was used instead of the GS2 ration, so differences in DMI in the present experiment could not be predicted from the SDMI index. However, in previous large-scale meta-analyses, the SDMI index has generally been a good indicator of the factors affecting silage DMI in both dairy cows (Huhtanen et al. 2002, 2007) and growing cattle (Huuskonen et al. 2013a). Earlier, Steen et al. (1998) examined factors affecting grass silage intake by growing beef steers. They determined the intakes of 136 silages from farms in Northern Ireland and produced multiple regression relationships between chemical parameters and intake. Also, these equations of Steen et al. (1998) predict that the intake potential ( $\mathrm{g} \mathrm{DM} \mathrm{kg}^{-1}$ metabolic LW) of the second cut silage should have been higher compared to the first cut silage in the present experiment.

In a recent meta-analysis, Huuskonen et al. (2013a) reported that DMI of growing cattle can be predicted from LW and diet composition with reasonable accuracy. Live weight was the most important variable predicting total feed intake, but the model was clearly improved when adjusted for dietary variables (NDF and VFA concentrations, SDMI index). Based on the equation reported by Huuskonen et al. (2013a) and the dietary compositions of the present rations, the predicted total DMI for GS1 and GS2 rations would have been 10.06 and $10.19 \mathrm{~kg} \mathrm{DM} \mathrm{d}^{-1}$, respectively, whereas the measured intakes were 9.93 and $9.17 \mathrm{~kg} \mathrm{DM} \mathrm{d}^{-1}$. Based on this, the realised DMI for GS1 ration was an expected result, but the GS2 ration resulted in a clearly lower intake than expected based on feed analysis. The same phenomenon has been found earlier in some milk production (Kuoppala et al. 2008, Sairanen et al. 2016) and beef cattle (Huuskonen and Pesonen 2017) experiments. For example, Sairanen et al. (2016) concluded that the high energy content of the autumn-cut silage was not realised as milk production and low total DMI was the main reason for the relatively low milk yield.

Mycotoxins were only found in second cut silage samples and none in first cut samples. In a review, Yiannikouris and Jouany (2002) stated that the contamination of feeds by mycotoxins generally leads to a decrease in intake. However, the effects of a single mycotoxin are conflicting and inconsistent results can be explained by the uncontrolled presence of other mycotoxins and their potential synergy (Yiannikouris and Jouany 2002). Therefore, it is difficult to estimate whether the mycotoxins were the most important factor that affected feed intake in the present study.

Higher daily DMI of the GS1 compared to the GS2 ration was reflected also as larger daily energy and nutrient intake. The observed difference in ME intake is probably the most important explanation for the improved LWG of the GS1 compared to the GS2 bulls. Based on a meta-analysis of growing cattle feeding experiments, Huuskonen and Huhtanen (2015) reported that energy intake is the most important dietary variable affecting LWG of growing cattle, whereas their results showed only marginal effects of protein supply on LWG. In the present experiment, the feed conversion rate did not differ between treatments. In some previous experiments silage DM concentration has affected on feed conversion, but the results are partly contradictory. Steen (1985) reported that carcass gain per unit of ME was similar for the treatments based on the wilted $\left(250 \mathrm{~g} \mathrm{DM} \mathrm{kg}^{-1}\right)$ and unwilted $\left(195 \mathrm{~g} \mathrm{DM} \mathrm{kg}^{-1}\right)$ silages in their experiment 2, but was $6 \%$ lower for the wilted $\left(259 \mathrm{~g} \mathrm{DM} \mathrm{kg}^{-1}\right)$ than for the unwilted $\left(191 \mathrm{~g} \mathrm{DM} \mathrm{kg}^{-1}\right)$ silages for experiment 1. O'Kiely et al. (1988) observed that unwilted silage (227 g DM kg-1) DM was converted 
more efficiently to carcass gain than DM of two wilted silages ( 313 and $397 \mathrm{~g} \mathrm{DM} \mathrm{kg}^{-1}$ ). However, the conclusions of Steen (1984) and Cottyn et al. (1985) suggest no difference between well-preserved unwilted and wilted silages in the feed conversion. In the experiment of Steen (1984) DM concentrations of unwilted and wilted silages were 161 and $266 \mathrm{~g} \mathrm{~kg}^{-1}$ and in the experiment of Cottyn et al. (1985) 209 and $328 \mathrm{~g} \mathrm{~kg}^{-1}$, respectively. Based on data from 85 published comparisons, Wright et al. (2000) concluded that there was no clear evidence that wilting reduced the efficiency of utilization of ME in growing cattle or in milk production.

The dressing proportion of the GS2 bulls tended to be slightly higher compared to the GS1 bulls in the present experiment. This could be because of the higher daily DMI and higher NDF concentration of the first cut silage compared to the second cut silage. According to Owens et al. (1995), a higher dietary NDF concentration generally promotes a greater gut fill. This kind of positive relationship between diet NDF concentration and gut fill has been reported earlier, for example, by Pond et al. (1987) and Rinne et al. (1997).

In the present study, feeding treatments had no effects on carcass conformation or carcass fat score. It is established that these traits generally increase with increasing carcass weight (Kempster et al. 1988, Keane and Allen 1998, Huuskonen et al. 2013b, 2014). In the present experiment, there was no difference in carcass weight between the feeding treatments so it is logical that no differences in carcass conformation or fat score were observed. Nevertheless, many previous reports have shown that also increasing energy intake has increased carcass conformation (Caplis et al. 2005, Pesonen et al. 2013, Huuskonen and Huhtanen 2015, Huuskonen et al. 2016) and carcass fatness (Huuskonen et al. 2007, Pesonen et al. 2013, Huuskonen and Huhtanen 2015) of finishing cattle, but these effects could not be demonstrated in the present experiment. It is possible that the effects of increasing energy intake on carcass traits are greater when the energy intake increases as a result of increasing dietary energy content instead of increasing voluntary feed intake as in the present experiment.

Overall, daily DM and energy intakes, as well as the live weight gain of the finishing bulls, decreased when the second cut timothy silage was used in the total mixed ration instead of the first cut silage. One possible reason for the decreased DMI in GS2 could be the presence of mycotoxins in second cut silage, but definite reasons were difficult to identify in this kind of feeding experiment. The dressing proportion of the GS2 bulls tended to be higher compared to the GS1 bulls which could be due to the higher NDF concentration of the first cut silage compared to the second cut silage.

\section{Acknowledgements}

This study was a part of NautaNurmi-project which was partially funded by the Centre for Economic Development, Transport and the Environment for Northern Ostrobothnia Finland, Ab Hanson \& Möhring, Eastman Chemical Company and Nordkalk Ltd. We wish to express our gratitude to Jarkko Kekkonen and his personnel for their technical assistance and excellent care of the experimental animals.

\section{References}

Boudra, H., Rouillé, B., Lyanc, B. \& Morgavi, D.P. 2015. Presence of mycotoxins in sugar beet pulp silage collected in France. Animal Feed Science and Technology 205: 131-135. https://doi.org/10.1016/j.anifeedsci.2015.04.010

Caplis. J., Keane, M.G., Moloney, A.P. \& O'Mara, F.P. 2005. Effects of supplementary concentrate level with grass silage, and separate or total mixed ration feeding, on performance and carcass traits of finishing steers. Irish Journal of Agricultural and Food Research 44: 27-43.

Cheli, F., Campagnoli, A. \& Dell'Orto, V. 2013. Fungal populations and mycotoxins in silages: From occurrence to analysis. Animal Feed Science and Technology 183: 1-16. https://doi.org/10.1016/j.anifeedsci.2013.01.013

Cottyn, B.G., Boucque, C.V., Fiems, L.O., Vanacker, J.M. \& Buysse, F.X. 1985. Unwilted and prewilted grass silage for finishing bulls. Grass and Forage Science 40: 119-125. https://doi.org/10.1111/j.1365-2494.1985.tb01728.x

Driehuis, F., Spanjer, M.C., Scholten, J.M. \& Te Giffel, M.C. 2008a. Occurrence of mycotoxins in maize, grass and wheat silage for dairy cattle in the Netherlands'. Food Additives and Contaminations 1: 41-50. https://doi.org/10.1080/19393210802236927

Driehuis, F., Spanjer, M.C., Scholten, J.M. \& Te Giffel, M.C. 2008b. Occurrence of mycotoxins in feedstuffs of dairy cows and estimation of total dietary intakes. Journal of Dairy Science 91: 4261-4271. https://doi.org/10.3168/jds.2008-1093

EC 2006. Council Regulation (EC) No 1183/2006 of 24 July 2006 concerning the Community scale for the classification of carcasses of adult bovine animals. Official Journal of European Union L214: 1-6.

Heikkilä, T., Toivonen, V. \& Huhtanen, P. 1998. Effect of spring and autumn silage, protein and concentrate level on milk production. In: Nagy, G. \& Petö, K. (eds.). Ecological aspects of grassland management. Proceedings of the 17th General Meeting of the European Grassland Federation, Debrecen Agricultural University, Debrecen, Hungary. p. 717-721. 
A. Huuskonen et al. (2018) 27: 232-242

Hietaniemi, V., Kontturi, M., Rämö, S., Eurola, M., Kangas, A., Niskanen, M. \& Saastamoinen, M. 2004. Contents of trichothecenes in oats during official variety, organic cultivation and nitrogen fertilization trials in Finland. Agricultural and Food Science 13: 5467. https://doi.org/10.2137/1239099041837996

Huhtanen, P., Khalili, H., Nousiainen, J.I., Rinne, M., Jaakkola, S., Heikkilä, T. \& Nousiainen, J. 2002. Prediction of the relative intake potential of grass silage by dairy cows. Livestock Production Science 73: 111-130. https://doi.org/10.1016/S0301-6226(01)00279-2

Huhtanen, P., Rinne, M. \& Nousiainen, J. 2007. Evaluation of the factors affecting silage intake of dairy cows; a revision of the relative silage dry matter intake index. Animal 1: 758-770. https://doi.org/10.1017/S175173110773673X

Huida, L., Väätäinen, H. \& Lampila, M. 1986. Comparison of dry matter contents in grass silage as determined by oven drying and gas chromatographic water analysis. Annales Agriculturae Fenniae 25: 215-230.

Huuskonen, A. \& Huhtanen, P. 2015. The development of a model to predict weight gain of growing cattle fed grass silage-based diets. Animal 9: 1329-1340. https://doi.org/10.1017/S1751731115000610

Huuskonen, A., Huhtanen, P. \& Joki-Tokola, E. 2013a. The development of a model to predict feed intake by growing cattle. Livestock Science 158: 74-83. https://doi.org/10.1016/j.livsci.2013.10.005

Huuskonen, A., Khalili, H. \& Joki-Tokola, E. 2007. Effects of three different concentrate proportions and rapeseed meal supplement to grass silage on animal performance of dairy-breed bulls with TMR feeding. Livestock Science 110: 154-165. https://doi. org/10.1016/j.livsci.2006.10.015

Huuskonen, A. \& Pesonen, M. 2017. A comparison of first-, second- and third-cut timothy silages in the diets of finishing beef bulls. Agricultural and Food Science 26: 16-24. https://doi.org/10.23986/afsci.60413

Huuskonen, A. \& Pesonen, M. 2018. Effects of replacing different proportions of barley grain by rye grain of performance of growing and finishing dairy bulls. Agricultural and Food Science 27: 152-158. https://doi.org/10.23986/afsci.70971

Huuskonen, A., Pesonen, M. \& Honkavaara, M. 2016. Performance and meat quality of Nordic Red and Aberdeen Angus bulls offered faba bean or field pea based whole crop legume-cereal silages. Agricultural and Food Science 25: 1-12. https://doi. org/10.23986/afsci.52311

Huuskonen, A., Pesonen, M. \& Honkavaara, M. 2017. Effects of replacing timothy silage by alsike clover silage on performance, carcass traits and meat quality of finishing Aberdeen Angus and Nordic Red bulls. Grass and Forage Science 72: 220-233. https:// doi.org/10.1111/gfs.12247

Huuskonen, A., Pesonen, M., Kämäräinen, H. \& Kauppinen, R. 2013b. A comparison of purebred Holstein-Friesian and Holstein-Friesian $\times$ beef breed bulls for beef production and carcass traits. Agricultural and Food Science 22: 262-271. https://doi. $\operatorname{org} / 10.23986 /$ afsci.7781

Huuskonen, A., Pesonen, M., Kämäräinen, H. \& Kauppinen, R. 2014. Production and carcass traits of purebred Nordic Red and Nordic Red $\times$ beef breed crossbred bulls. Journal of Agricultural Science 152: 504-517. https://doi.org/10.1017/S0021859613000749

Keady, T.W., Lively, F.O., Kilpatrick, D.J. \& Moss, B.W. 2008. The effects of grain treatment, grain feed level and grass silage feed value on the performance of and meat quality from, finishing beef cattle. Animal 2: 149-159. https://doi.org/10.1017/ S1751731107000948

Keane, M.G. \& Allen, P. 1998. Effects of production system intensity on performance, carcass composition and meat quality of beef cattle. Livestock Production Science 56: 203-214. https://doi.org/10.1016/S0301-6226(98)00155-9

Kempster A.J., Cook G.L. \& Southgate J.R. 1988. Evaluation of British Friesian, Canadian Holstein and beef breed $\times$ British Friesian steers slaughtered over a commercial range of fatness from 16-month and 24-month beef production systems. 2. Carcass characteristics, and rate and efficiency of lean gain. Animal Production 46: 365-378. https://doi.org/10.1017/S0003356100018973

Kuoppala, K. 2010. Influence of harvesting strategy on nutrient supply and production of dairy cows consuming diets based on grass and red clover silage. Doctoral Dissertation. University of Helsinki, Department of Agricultural Sciences. MTT Science 11. $51 \mathrm{p}$.

Kuoppala, K., Rinne, M., Nousiainen, J. \& Huhtanen, P. 2008. The effect of cutting time of grass silage in primary growth and regrowth and the interactions between silage quality and concentrate level on milk production of dairy cows. Livestock Science 116: 171-182. https://doi.org/10.1016/j.livsci.2007.10.002

Luke 2018. Feed Tables and Nutrient Requirements. (cited 25. August 2018). http://www.luke.fi/feedtables

Manninen, M., Honkavaara, M., Jauhiainen, L., Nykänen, A. \& Heikkilä, A.-M. 2011. Effects of grass-red clover silage digestibility and concentrate protein concentration on performance, carcass value, eating quality and economy of finishing Hereford bulls reared in cold conditions. Agricultural and Food Science 20: 151-168. https://doi.org/10.2137/145960611797215691

Ministry of Agriculture, Fisheries and Food (MAFF). 1984. Energy Allowances and Feeding Systems for Ruminants. ADAS Reference book 433. Ministry of Agriculture, Fisheries and Food. Her Majesty`s Stationery Office, London. 85 p.

Moisio, T. \& Heikonen, M. 1989. A titration method for silage assessment. Animal Feed Science and Technology 22: 341-353. https://doi.org/10.1016/0377-8401(89)90078-3

Nousiainen, J., Ahvenjärvi, S., Rinne, M., Hellämäki, M. \& Huhtanen, P. 2004. Prediction of indigestible cell wall fraction of grass silage by near infrared reflectance spectroscopy. Animal Feed Science and Technology 115: 295-311. https://doi.org/10.1016/j. anifeedsci.2004.03.004

Offer, N.W., Percival, D.S., Dewhurst, R.J. \& Thomas, C. 1998. Prediction of the voluntary intake potential of grass silage by sheep and dairy cows from laboratory silage measurements. Animal Science 66: 357-367. https://doi.org/10.1017/S1357729800009486

O'Kiely, P., Flynn, A.V. \& Wilson, R.K. 1988. A comparison of the chemical composition of unwilted and wilted grass silage and of the intake, performance, carcass composition and rumen fluid volatile fatty acid concentrations of steers fed the silages. Irish Journal of Agricultural Research 27: 39-50.

Owens, F.N., Gill, D.R., Secrist, D.S. \& Coleman, S.W. 1995. Review of some aspects of growth and development of feedlot cattle. Journal of Animal Science 73: 3152-3172. https://doi.org/10.2527/1995.73103152x 
Peoples, A.C. \& Gordon, F.J. 1989. The influence of wilting and season of silage harvest and the fat and protein concentration of the supplement on milk production and food utilization by lactating cattle. Animal Production 48: 305-317. https://doi.org/10.1017/ S0003356100040307

Pesonen, M., Honkavaara, M., Kämäräinen, H., Tolonen, T., Jaakkola, M., Virtanen, V. \& Huuskonen, A. 2013. Effects of concentrate level and rapeseed meal supplementation on performance, carcass characteristics, meat quality and valuable cuts of $\mathrm{He}$ reford and Charolais bulls offered grass silage-barley-based rations. Agricultural and Food Science 22: 151-167. https://doi. org/10.23986/afsci.6703

Pesonen, M. \& Huuskonen, A. 2015. Production, carcass characteristics and valuable cuts of beef breed bulls and heifers in Finnish beef cattle population. Agricultural and Food Science 24: 164-172. https://doi.org/10.23986/afsci.50930

Pond, K.R., Ellis, W.C., Lascano, C.E. \& Akin, D.E. 1987. Fragmentation and flow of grazed coastal bermudagrass through the digestive tract of cattle. Journal of Animal Science 65: 609-618. https://doi.org/10.2527/jas1987.652609x

Rinne, M., Huhtanen, P. \& Jaakkola, S. 1997. Grass maturity effects on cattle fed silage-based diets. 2. Cell wall digestibility, digestion and passage kinetics. Animal Feed Science and Technology 67: 19-35. https://doi.org/10.1016/S0377-8401(96)01142-X

Sairanen, A., Palmio, A. \& Rinne, M. 2016. Milk production potential of regrowth grass silages. Grassland Science in Europe 21: 379-381.

Scollan, N.D., Sargeant, A., McAllan, A.B. \& Dhanoa, M.S. 2001. Protein supplementation of grass silages of differing digestibility for growing steers. Journal of Agricultural Science 136: 89-98. https://doi.org/10.1017/S002185960000856X

Schneweis, I., Meyer, K., Hormansdorfer, S. \& Bauer, J. 2000. Mycophenolic acid in silage. Applied and Environmental Microbiology 66: 3639-3641. https://doi.org/10.1128/AEM.66.8.3639-3641.2000

Stead, S., Roberts, D., Gledhill, A., de Rijk, T., Van Poucke, C. \& De Saeger, S. 2014. The development of a sensitive multi-residue LC-MS/MS method for the quantitative determination of mycotoxins in animal feedstuffs and silage using Xevo TQ-S. Waters: Application Note. 9 p. http://www.waters.com/webassets/cms/library/docs/720004961en.pdf

Steen, R.W.J. 1984. A comparison of unwilted and wilted grass silages offered to beef cattle without and with monensin sodium. Grass and Forage Science 39: 35-41. https://doi.org/10.1111/j.1365-2494.1984.tb01662.x

Steen, R.W.J. 1985. The effect of field wilting and mechanical treatment on the feeding value of grass silage for beef cattle and on beef output per hectare. Animal Production 41: 281-291. https://doi.org/10.1017/S0003356100036333

Steen, R.W.J. 1988. Factors affecting the utilization of grass silage for beef production. In: Frame J. (ed.). Efficient Beef Production from Grass. Occasional Symposium No. 22, British Grassland Society, Hurley, UK. p. 129-139.

Steen, R.W.J., Gordon, F.J., Dawson, L.E.R., Park, R.S., Mayne, C.S., Agnew, R.E., Kilpatrick, D.J. \& Porter, M.G. 1998. Factors affecting the intake of grass silage by cattle and prediction of silage intake. Animal Science 66: 115-127. https://doi.org/10.1017/ S1357729800008894

Wright, D.A., Gordon, F.J., Steen, R.W.J. \& Patterson, D.C. 2000. Factors influencing the response in intake of silage and animal performance after wilting of grass before ensiling: a review. Grass and Forage Science 55:1-13. https://doi.org/10.1046/j.13652494.2000.00198.x

Yiannikouris, A. \& Jouany, J.-P. 2002. Mycotoxins in feeds and their fate in animals: a review. Animal Research 51: 81-99. https:// doi.org/10.1051/animres:2002012 